\title{
АНАЛІЗ ДИНАМІКИ ПРИЧИН ДОРОЖНЬО-ТРАНСПОРТНИХ ПРИГОД І ПРОГНОЗУВАННЯ НЕБЕЗПЕЧНИХ ПОДІЙ
}

\author{
Іван Городецький, к. т. н., Василь Тимочко, к. т. н., Ігор Мазур, к. с.-Г. н., \\ Ігор Городецький, Андрій Березовецький, к. т. н. \\ Львівський національний аграрний університет, \\ вул. Володимира Великого, 1, м. Дубляни, Львівський р-н, Львівська обл., Украӥна, \\ e-mail:ivanhorod@gmail.com
}

https://doi.org/10.31734/agroengineering2021.25.182

\begin{abstract}
Городецький І., Тимочко В., Мазур І., Городецький І., Березовецький А. Аналіз динаміки причин дорожньотранспортних пригод і прогнозування небезпечних подій

Охарактеризовано проблему дорожньо-транспортних пригод (ДТП) і значного травматизму на дорогах у світі та Україні. Щорічно у світовому вимірі від аварій на дорогах гине 1,35 млн осіб, із яких майже 50 \% - це пішоходи, велосипедисти і мотоциклісти. Країни втрачають близько $3 \%$ внутрішнього валового продукту; також простежується залежність: чим вищий розвиток країни, тим кількість дорожньо-транспортних пригод є меншою. Аналогічно це стосується віку транспортного засобу: чим новіший автомобіль, тим менше потрапляє у дорожньотранспортну пригоду. Проаналізовано причини ДТП, бо їх вивчення дає змогу планувати і впроваджувати заходи щодо зниження кількості небезпечних умов, обставин і ситуацій у системі «водій - автомобіль - дорога довкілля». Віднедавна в Україні основними причинами ДТП і пов'язаного з ними травматизму було перевищення безпечної швидкості (7586-9999 подій), проблеми під час маневрування (5201-5522), порушення на перехрестях (2959-2352), недостатня дистанція (2420-1445), порушення на пішохідних переходах (1683-1680), керування транспортом у нетверезому стані (911-1819) тощо. Згідно з оцінкою динаміки причин ДТП в Україні, найбільше зросла кількість таких небезпечних подій: порушення вимог безпеки пасажиром (+73\%), перевищення безпечної швидкості руху транспортного засобу $(+31,8$ \%), порушення правил проїзду пішохідних переходів $(+10,5$ \%) та ін. Динаміка травматизму під час дорожньо-транспортних пригод має негативну тенденцію зростання від 24294 до 26141 випадку за останні три роки, а прогнозування продемонструвало подальше їх збільшення. Тому потрібно планувати і створювати зовнішні впливи для нормалізації ситуації на дорогах України - законодавчі, управлінські, технічні, організаційні тощо.
\end{abstract}

Ключові слова: безпека, небезпека, прогнозування, дорожньо-транспортна пригода, аварія, травматизм.

Horodetskyi I., Tymochko V., Mazur I., Horodetskyi I., Berezovetskyi A. Analysis of the dynamics of causes of traffic accidents and forecasting dangerous events

The problem of the road accidents and significant injuries on the roads is described. Every year, 1.35 million people die in road accidents worldwide, of which about $50 \%$ are pedestrians, cyclists and motorcyclists, and countries lose about $3 \%$ of the gross domestic product. There is also a dependence that the higher is the country's development, the lower is the number of road accidents, similarly to the age of the vehicle - the newer is the car, the less it gets into a road accident. The causes of the road accidents in Ukraine are analyzed for the years of 2018-2020, because their study allows planning and implementing the measures to reduce hazards in the system of "Driver - Car - Road - Environment". In recent years, the main causes of the accidents and related injuries in Ukraine were: speeding (7586-9999 events), maneuvering problems (5201-5522), violations at intersections (2959-2352), insufficient distance (2420-1445), violations at pedestrian crossings (1683-1680), drunk driving (911-1819), etc. Assessment of the dynamics of the accident causes showed the largest increase in the following dangerous events - passenger safety violations $(+73 \%)$, exceeding the safe speed of the vehicle (+ $31.8 \%$ ), violation of the rules of pedestrian crossings ( $+10.5 \%)$ and etc. The dynamics of injuries during road accidents has a negative trend of growth from 24294 to 26141 cases over the past three years in Ukraine, and forecasting has shown a further increase, so one needs to plan and create external influences to normalize the situation - legislative (additional regulation of traffic), managerial (to create and implement managerial measures of road safety), technical (to create new means of car and road safety), organizational (to organize a higher level of car and road safety measurers) and others.

Key words: safety, danger, forecasting, road accident, accident, injury.

Постановка проблеми. Порушення правил безпеки водіями, пасажирами, пішоходами та ін., що призводить до дорожньо-транспортних пригод (ДТП), - проблема, яка виникла від початку автомобілебудування й актуальна досі. Кількість ДТП як в Україні, так і у світі чимала. Щорічно у світі від аварій на дорогах гине 1,35 млн осіб, із яких $50 \%$ - це пішоходи, велосипедисти i 
мотоциклісти [16; 17]. За даними Національної поліції в Україні, щорічно збільшується кількість загиблих унаслідок ДТП: 3350 - у 2018 р., 3454 - у 2019 р., 3541 - у 2020 р. Згідно зі статистичними даними, у 2018 р. внаслідок ДТП травмовано 30884 особи, у 2019 р. - 32736, у 2020 р. - 31974 [11].

Аналіз останніх досліджень і публікацій. Умови, обставини, небезпечні дії та інші проблеми, що призводять до виникнення ДТП, досліджують як в Україні, так і за кордоном. Ці пошуки спрямовані і на аналіз причин травматизму, і на розроблення заходів із запобігання процесам формування травмонебезпечних та аварійних ситуацій на дорогах різного призначення і локалізації.

Автори [17; 21] характеризують причини ДТП у Польщі. Найпоширенішими причинами аварій, що сталися через технічний стан автомобілів, є недоліки системи освітлення, які погіршують видимість, і несправності в гальмівній системі. Встановлено, що кількість ДТП з роками зростає, як і кількість травмованих у ДТП, а кількість летальних наслідків знижується; збільшується кількість травмованих дітей до 14 років, а також нетверезих учасників руху (на прикладі Поморського воєводства 3 найгіршими показниками). Автор [17] аналізує летальні випадки на дорогах Польщі залежно від віку пасажирських автомобілів. Він визначив, що автомобілі віком до 5 років найкраще захищають водіїв, тобто важкі травмування в ДТП виникають утричі частіше зі старшими автомобілями порівняно з новими віком до 5 років.

У праці [5] охарактеризовано основні причини скоєння ДТП та їх наслідки в Україні стосовно ДТП з постраждалими і конкретно пішоходів. Установлено, що ДТП з травмуванням осіб були скоєні за умови виїзду на смугу зустрічного руху - $21 \%$ від усіх ДТП із постраждалими, за перевищення безпечної швидкості руху (25\%), через проблеми керування $(11 \%)$ тощо. Також подано динаміку наїздів на пішоходів до 2018 р. i зроблено спробу аналізу процесу формування травмонебезпечних та аварійних ситуацій в умовах перехресть доріг у містах 3 наголошенням на помилкових діях водіїв і пішоходів, конфліктних ситуаціях на дорозі. Автори [19] подають результати досліджень аварій за участю пішоходів у США за 2007-2018 pp. 3 урахуванням неоднорідності таких аварійних процесів автори розробили модель із випадковими параметрами для ідентифікації конкретних чинників, що впливають на процеси розвитку небезпек. Значущими чинниками є характеристики пішохода, транспортного засобу, типу аварії, місцевості, проїжджої частини, навколишнього середовища, часу та характеристик контролю руху тощо, виявлені під час аналізу.

3 метою запобігання аваріям автори [18] розробили методику оцінки стресу водіїв, який виникає під час водіння у великих містах, зокрема під час переїзду перехресть, i впливу на водія множини сигналів. Для виявлення афективного стану проаналізовано поворот з одним і кількома рухами, виявлено мінливість продуктивності, що дає змогу отримати відтворювані та надійні результати й запроваджувати захисні заходи.

У статті [1] наголошено на значних економічних і соціальних втратах від травматизму під час ДТП, системній кризі боротьби з аварійністю на автомобільних дорогах країни, оскільки кількість потерпілих зростає. Статистичні дані свідчать, що здебільшого причиною виникнення ДТП є порушення правил дорожнього руху (ПДР), i для поліпшення ситуації потрібно використовувати досвід провідних країн світу, які успішно долають травматизм на дорогах запровадженням загальної культури руху, оптимальних керівних впливів, загальнонаціональних комплексних програм, підвищенням безпеки транспортних засобів і доріг, удосконаленням інформаційного забезпечення, нормативних документів тощо.

Дослідження авторів [8; 9; 13] спрямовані на запобігання причинам ДТП на основі розроблених організаційних і технічних заходів. Зокрема, з метою підвищення безпеки пішоходів i зменшення часу очікування автомобілів у заторах пропонується розвантаження перехресть унаслідок зміни місця пішохідних переходів і громадських зупинок транспорту, розширення шини проїзної частини вулиць. Також автори аналізують технічні несправності автомобіля, які стали причиною ДТП у Польщі, наголошуючи, що вчасне діагностування параметрів технічного стану дає змогу підвищувати безпеку на дорогах. На основі методу МАФР дослідники моделюють функцію контролю за безпекою руху автомобіля внаслідок зміни його технічного стану, що впливає на погіршення керованості, стійкості та інших якостей у процесі експлуатації, удосконалюють організацію діагностики. У роботі [4] проаналізовано математичні методи обгрунтування рішень для розв'язування задач автотехнічної експертизи ДТП i визначено напрями вдосконалення наявних i розроблення нових методів для підвищення точності розрахунків, що передують експертним висновкам. 
Автор [20] аналізує засоби активної безпеки автомобіля і їхню роль у поліпшенні безпеки руху. Водночас обгрунтовано необхідність розробки систем, які дозволяють або нейтралізують надлишкові керівні впливи, коригують недостатні керівні дії водія.

Дослідження параметрів дорожнього покриття на перехресті і їхнього впливу на виникнення ДТП [15] виявили, що рівень освітленості, вологість дорожнього покриття, інтенсивність руху є важливими чинниками виникнення аварійних ситуацій, також мають значення геометричні змінні дороги, наявність спільної смуги руху, автобусної зупинки тощо. Загалом покращання стану дорожнього покриття, інші параметри дороги, професійні навички, досвід i стан водія й транспортного засобу, гармонійний розвиток системи «водій - транспортний засіб дорога - довкілля» значно зменшують частоту аварій та рівень їх важкості.

Постановка завдання. Наше завдання проаналізувати динаміку причин ДТП в Україні і спрогнозувати виникнення травмонебезпечних подій; а також вивчити причини й узагальнити схеми процесу формування травмонебезпечних $\mathrm{i}$ аварійних ситуацій, що дасть змогу планувати запобіжні заходи для зниження рівня травматизму на дорогах.

Виклад основного матеріалу. ПДР містять визначення ДТП як події, що сталася під час руху транспортного засобу, внаслідок якої загинули або поранені люди чи завдано матеріальної шкоди [7], тобто йдеться про розвиток процесів формування травмонебезпечних та аварійних ситуацій. Розслідування небезпечних подій дає змогу встановити причини їх формування й розвитку, а статистичні дані - аналізувати стан явища в динаміці та планувати запобіжні заходи. Статистичні дані стосовно причин ДТП за роками отримано з офіційного сайту Департаменту патрульної поліції (табл. 1), а дані виробничого травматизму за галузями - зі сайту Державної служби України 3 питань праці та Державної служби статистики [10; 12].

Аналіз статистичних даних засвідчує, що причини виникнення ДТП згруповані у 28 позицій, від мінімальних значень (як-от: загальна кількість - 16 ДТП із причини порушення правил проїзду зупинок громадського транспорту чи 28 через порушення правил користування зовнішніми світловими приладами транспортних засобів у 2020 р.) до максимальної кількості (загальна кількість - 69252 ДТП із причини порушення правил маневрування чи 38769 ДТП через перевищення безпечної швидкості транспортних засобів у 2020 р.) [10]. Окрема систематизація дає змогу кількісно оцінити, скільки інцидентів сталося 3 вини водіїв, а скільки - 3 вини утримувачів чи власників вулично-шляхової мережі. Окремо реєструють інциденти 3 пішоходами та дітьми. Важливі показники незадовільного стану доріг, зокрема за їхніми категоріями. Також відзначають ДТП, скоєні за умов незадовільного стану вулиць тощо.

Причини мають важливе значення для аналізу ДТП, оскільки їх вивчення дає змогу планувати відповідні заходи для зниження впливу конкретного виду дій і подій, які є небезпечними для учасників дорожнього руху. Аналіз причин продемонстрував, що віднедавна основними небезпечними діями водіїв, що призвели до ДТП з потерпілими, $\epsilon:$ 1) перевищення безпечної швидкості (зростання з 7586 ДТП у 2017 р. до 9999 у 2020 р., під час яких отримали травми від 9944 у 2017 р. до 11411 осіб у 2020 р., що свідчить про зростання на 25,2 і 31,8 \%); 2) порушення правил маневрування (зростання 35201 ДТП у 2017 р. до 5522 у 2020 р., під час яких отримали травми від 6458 у 2017 р. до 6775 осіб у 2020 р.; 3) порушення правил проїзду пішохідних переходів (з 1683 ДТП у 2017 р. до 1860 у 2020 р., під час яких отримали травми від 1723 у 2017 р. до 1879 осіб у 2020 р.); 4) порушення правил проїзду перехресть (з 2959 ДТП у 2017 р. до 2352 у 2019 р., під час яких отримали травми від 4176 у 2017 р. до 3059 осіб у 2020 р.); 5) недотримання дистанції (з 2420 ДТП у 2017 р. до 1445 у 2020 р., під час яких отримали травми від 3108 у 2017 р. до 1687 осіб у 2020 р.); 6) керування транспортним засобом у нетверезому стані (з 1819 ДТП у 2017 р. до 911 у 2020 р., під час яких отримали травми від 2396 у 2017 р. до 1554 осіб у 2020 р.) та ін. Що стосується пішоходів, то з причини переходу у невстановленому місці сталося 1095 ДТП у 2017 р. i 1102 у 2019 р., з потерпілими від 962 осіб у 2017 р. до 942 у 2019 р. У 2020 р. було незначне зниження кількості таких ДТП (992 випадки і 821 потерпілий).

Аналіз динаміки причин ДТП показав, що останніми роками найбільшого зростання зазнали такі небезпечні дії водіїв: перевищення безпечної швидкості $(+23,1 \%)$, або на 1467 осіб травмованих більше у 2020 р. порівняно з 2017 р.; порушення правил проїзду перехресть $(+11,65)+441$, або на 269 травмованих більше у 2020 р. порівняно з 2018 р.; порушення правил проїзду пішохідних переходів $(+10,5 \%)+177$, або на 156 травмованих більше у 2020 р. порівняно 32018 р.; 
порушення правил маневрування (+6,2%) +321, або на 317 травмованих більше у 2020 р. порівняно 32017 р. та ін. Щодо небезпечних дій інших учасників ДТП, зокрема пішоходів і пасажирів, то збільшилася кількість ДТП з причин: порушення техніки безпеки пасажиром (+73,3 \%) +33 випадки
ДТП, або на 42 травмованих більше у 2020 р. порівняно з 2017 р.; участь у ДТП пішоходів у нетверезому стані $(+9,1 \%)+10$ за період 20182019 pp. та ін. Динаміку загальної кількості ДТП, травмування учасників і їхній розподіл за роками відображено у табл. 2 [10].

Таблиця 1. Динаміка деяких причин дорожньо-транспортних пригод і рівень травмування

Table 1. The dynamics of some reasons of road accidents and the level of injuries

\begin{tabular}{|c|c|c|c|c|c|c|c|c|c|c|c|c|c|}
\hline \multirow{3}{*}{ Причини ДТП } & \multicolumn{12}{|c|}{ ДТП з потерпілими } & \multirow{3}{*}{\begin{tabular}{|c}
2020 p. \\
до \\
2017 p. \\
ДТП/ле \\
тал., \%
\end{tabular}} \\
\hline & \multicolumn{4}{|c|}{ ДТП } & \multicolumn{4}{|c|}{ Загинуло, осіб } & \multicolumn{4}{|c|}{ Травмовано, осіб } & \\
\hline & 2017 & 2018 & 2019 & 2020 & 2017 & 2018 & 2019 & 2020 & 2017 & 2018 & 2019 & 2020 & \\
\hline $\begin{array}{l}\text { Керування } \\
\text { транспортним засобом } \\
\text { у нетверезому стані }\end{array}$ & 1819 & 968 & 1216 & 911 & 246 & 87 & 106 & 103 & 2396 & 1306 & 1616 & 1554 & $\begin{array}{l}50,1 / \\
41,9\end{array}$ \\
\hline $\begin{array}{l}\text { Перевищення } \\
\text { встановленої } \\
\text { швидкості }\end{array}$ & 608 & 575 & 576 & 522 & 139 & 162 & 127 & 143 & 742 & 708 & 751 & 719 & $\begin{array}{l}85,9 / \\
102,9\end{array}$ \\
\hline $\begin{array}{l}\text { Перевищення } \\
\text { безпечної швидкості }\end{array}$ & 7586 & 8279 & 8761 & 9999 & 1418 & 1502 & 1539 & 1776 & 9944 & 10351 & 10855 & 11411 & $\begin{array}{l}131,8 / \\
125,2\end{array}$ \\
\hline $\begin{array}{l}\text { Невиконання вимог } \\
\text { сигналів регулювання }\end{array}$ & 392 & 306 & 338 & 335 & 4 & 11 & 15 & 15 & 541 & 436 & 459 & 468 & $\begin{array}{c}85,5 / \\
375 \\
\end{array}$ \\
\hline $\begin{array}{l}\text { Порушення правил } \\
\text { перевезення пасажирів }\end{array}$ & 106 & 110 & 86 & 65 & 2 & 5 & 8 & 6 & 108 & 120 & 94 & 88 & $\begin{array}{c}61,3 / \\
300 \\
\end{array}$ \\
\hline $\begin{array}{l}\text { Порушення правил } \\
\text { маневрування }\end{array}$ & 5201 & 5252 & 5676 & 5522 & 429 & 550 & 594 & 534 & 6458 & 6682 & 7128 & 6775 & $\begin{array}{l}106,2 / \\
124,5 \\
\end{array}$ \\
\hline $\begin{array}{l}\text { Порушення правил } \\
\text { проїзду пішохідних } \\
\text { переходів }\end{array}$ & 1683 & 1602 & 1673 & 1860 & 78 & 87 & 108 & 113 & 1723 & 1662 & 1674 & 1879 & $\begin{array}{c}110,5 / \\
144,9\end{array}$ \\
\hline $\begin{array}{l}\text { Порушення правил } \\
\text { надання безперешкод- } \\
\text { ного проїзду }\end{array}$ & 469 & 261 & 264 & 245 & 17 & 30 & 21 & 9 & 652 & 411 & 392 & 287 & $\begin{array}{l}52,2 / \\
52,9\end{array}$ \\
\hline $\begin{array}{l}\text { Порушення правил } \\
\text { обгону }\end{array}$ & 458 & 289 & 317 & 285 & 67 & 60 & 60 & 53 & 689 & 493 & 540 & 529 & $\begin{array}{l}62,2 / \\
79,1 \\
\end{array}$ \\
\hline $\begin{array}{l}\text { Виїзд на смугу } \\
\text { зустрічного руху }\end{array}$ & 1024 & 830 & 778 & 643 & 285 & 232 & 234 & 173 & 1814 & 1622 & 1449 & 1309 & $\begin{array}{l}62,8 / \\
60,7 \\
\end{array}$ \\
\hline $\begin{array}{l}\text { Порушення правил } \\
\text { проїзду перехресть }\end{array}$ & 2959 & 1911 & 2132 & 2352 & 124 & 80 & 92 & 104 & 4176 & 2790 & 3060 & 3059 & $\begin{array}{l}79,5 / \\
83,9 \\
\end{array}$ \\
\hline $\begin{array}{l}\text { Недотримання } \\
\text { дистанції }\end{array}$ & 2420 & 1716 & 1967 & 1445 & 124 & 108 & 128 & 85 & 3108 & 2344 & 2662 & 1687 & $\begin{array}{l}59,7 / \\
68,5\end{array}$ \\
\hline $\begin{array}{l}\text { Перевтома, сон за } \\
\text { кермом }\end{array}$ & 107 & 79 & 90 & 111 & 33 & 22 & 27 & 23 & 149 & 94 & 121 & 88 & $\begin{array}{c}103,7 / \\
69,7\end{array}$ \\
\hline $\begin{array}{l}\text { Перехід у } \\
\text { невстановленому місці }\end{array}$ & 1095 & 1057 & 1102 & 992 & 213 & 230 & 216 & 227 & 962 & 865 & 942 & 821 & $\begin{array}{l}90,6 / \\
106,6 \\
\end{array}$ \\
\hline $\begin{array}{l}\text { Неочікуваний вихід на } \\
\text { проїзну частину }\end{array}$ & 640 & 510 & 511 & 403 & 122 & 100 & 99 & 94 & 553 & 424 & 427 & 313 & $\begin{array}{l}62,9 / \\
77,1 \\
\end{array}$ \\
\hline $\begin{array}{l}\text { Пішохід у нетверезому } \\
\text { стані }\end{array}$ & 211 & 110 & 120 & 54 & 41 & 20 & 17 & 16 & 180 & 92 & 102 & 38 & $\begin{array}{l}25,6 / \\
39,0 \\
\end{array}$ \\
\hline $\begin{array}{l}\text { Порушення техніки } \\
\text { безпеки пасажиром }\end{array}$ & 45 & 92 & 79 & 78 & 9 & 6 & 6 & 4 & 40 & 89 & 75 & 82 & $\begin{array}{c}173,3 / \\
44,4 \\
\end{array}$ \\
\hline
\end{tabular}


Таблиця 2. Загальна динаміка дорожньо-транспортних пригод і рівень травмування

Table 2. The general dynamics of road accidents and the level of injury

\begin{tabular}{|l|c|c|c|c|}
\hline \multicolumn{1}{|c|}{ Категорії/роки } & 2018 & 2019 & 2020 & Динаміка 2020 р. до 2017 p. \\
\hline Всього ДТП в Україні & 150120 & 160675 & 168107 & 111,9 \\
\hline Травмовано, осіб & 30884 & 32736 & 31974 & 103,5 \\
\hline ДТП з травмованими & 24294 & 26052 & 26140 & 107,6 \\
\hline Загинуло, осіб & 3350 & 3454 & 3541 & 105,7 \\
\hline
\end{tabular}

Аналіз динаміки загальної кількості ДТП за роками (див. табл. 2) демонструє зростання всіх показників у межах від 3,5 до 11,9 \%, що $\epsilon$ негативним як для учасників дорожнього руху, так і для держави загалом. На нашу думку, причинами цього є недоліки функціонування системи «водій транспортний засіб - дорога - довкілля» (див. табл. 1), а також зростання кількості транспортних засобів за роками (за 2018-2020 рр. кількість велосипедів, моторолерів, мопедів, скутерів збільшилася з 57 до 67, автомобілів, мікроавтобусів - 3
25 до 30 у середньому на 100 домогосподарств [6]).

Дослідження динаміки причин ДТП і їх аналіз дають змогу оцінювати безпеку на дорогах за небезпечними діями водіїв, пасажирів, пішоходів, формулювати напрями запобігання травмонебезпечним і аварійним ситуаціям. На рис. 1, 2 подано результати аналізу динаміки небезпечних подій, що $\epsilon$ причинами ДТП і травматизму, а також прогнозування на майбутній період 3 аналітичними залежностями розвитку процесів.
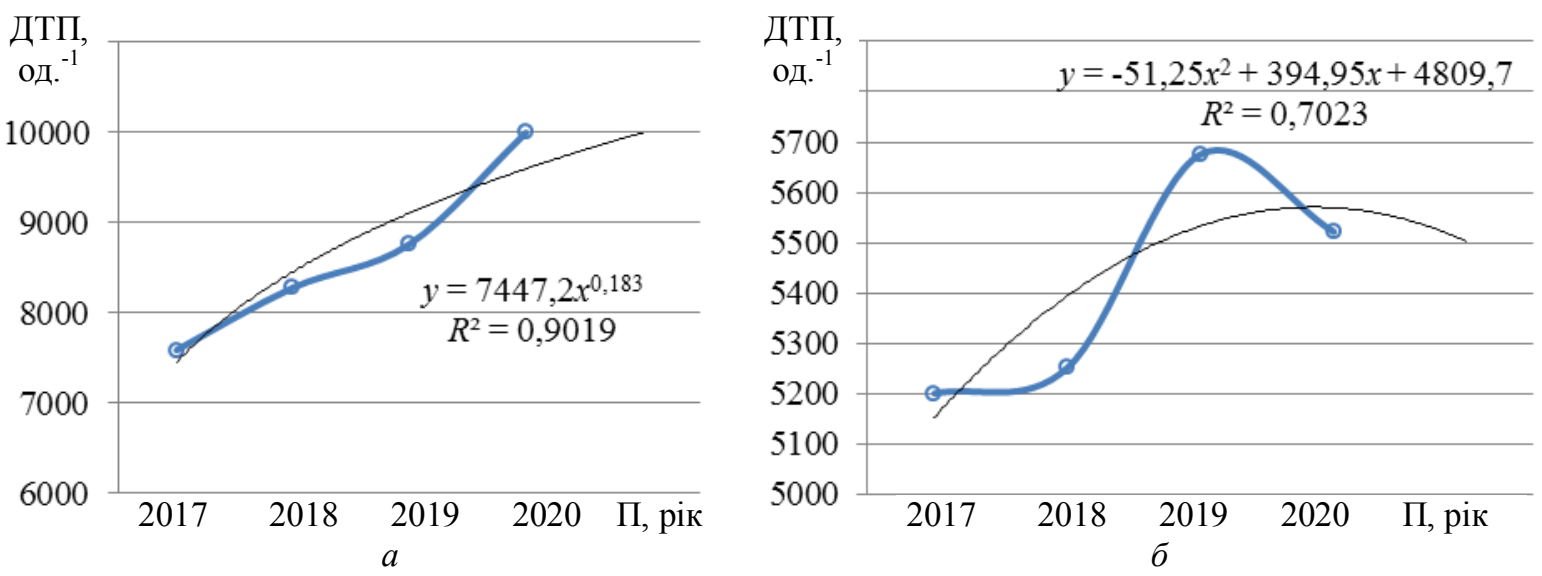

Рис. 1. Динаміка і прогнозування ДТП залежно від: $a$ - перевищення безпечної швидкості руху; $\sigma$ - порушення правил маневрування

Fig. 1. Dynamics and forecasting of road accidents depending on: $a$-exceeding the safe speed; $\sigma$ - violation of maneuvering rules
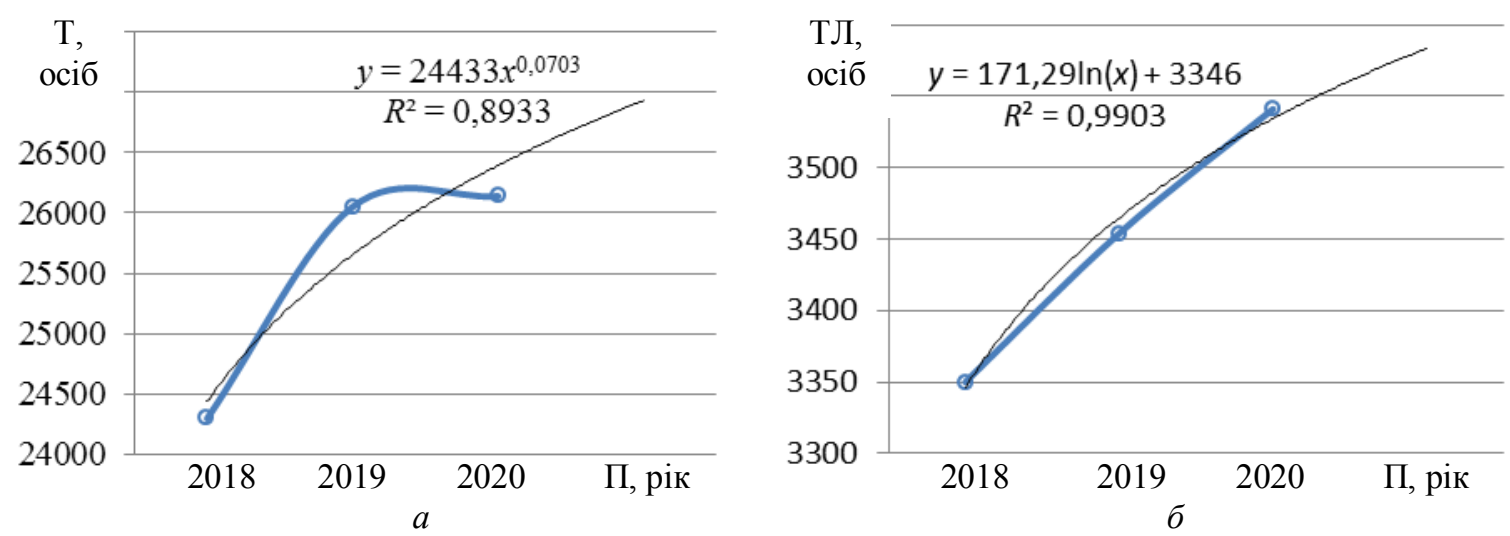

Рис. 2. Динаміка і прогнозування травматизму: $a$ - ДТП з травмованими особами; $\sigma$ - загинуло осіб. Fig. 2. Dynamics and forecast of injuries: $a$-road accident with people injured; $\sigma$ - people died. 
Графіки динаміки ДТП останніми роками в Україні показали їх негативну динаміку зростання через перевищення швидкості руху (упродовж усіх років) і порушення правил маневрування у 2017-2019 pp. (у 2020 p. - спадання). Прогнозування продемонструвало подальше збільшення 3 причини перевищення швидкості і значне зростання та незначне зменшення з причини порушення правил маневрування.

Аналіз і прогнозування ДТП і травматизму за останні роки в Україні показали негативну тенденцію до зростання через низку встановлених у табл. 1 причин, небезпечних дій, обставин, виробничих чинників, умов, що призвели до небезпечних ситуацій. На основі аналізу такого стану у межах підприємств, галузей чи держави потрібно запроваджувати коригувальні дії законодавчого, організаційного, управлінського чи технічного характеру, окреслені як у наших дослідженнях $[2 ; 3 ; 14]$, так і в розробках інших авторів, детальніше подані в літературному огляді. Такий вплив на суб'єкти, об'єкти та причини ДТП суттєво знизить їхній рівень, про що свідчить статистика розвинутих країн.

Висновки. Проаналізовано причини ДТП, бо їх вивчення дає змогу планувати і впроваджувати заходи щодо зниження небезпек у системі «водій - автомобіль - дорога - довкілля». Віднедавна основними причинами ДТП і пов'язаного з ними травматизму є перевищення безпечної швидкості (7586-9999 подій), проблеми під час маневрування (5201-5522), порушення на перехрестях (2959-2352), недостатня дистанція (2420-1445), порушення на пішохідних переходах (1683-1680), керування транспортом у нетверезому стані (911-1819) тощо. Оцінка динаміки причин ДТП за останні роки демонструє частоту виникнення таких подій, як порушення безпеки пасажиром (+73\%), перевищення безпечної швидкості руху транспортного засобу $(+31,8 \%)$, порушення правил проїзду пішохідних переходів $(+10,5 \%)$ тощо. Динаміка травматизму під час ДТП має негативну тенденцію зростання від 24294 до 26141 випадку, а прогнозування виявило подальше їх збільшення. Тому для нормалізації ситуації на дорогах потрібно планувати і створювати зовнішні впливи - організаційні, законодавчі, технічні та ін.

\section{Бібліографічний список}

1. Аналіз існуючого стану автомобілізації та системна криза боротьби з аварійністю на автомобільних дорогах / В. П. Поліщук та ін. Вісник Наџіонального транспортного університету. Технічні науки. 2016. Вип. 1 (34). С. 354-363.

2. Городецький I. М., Мазур I. Б., Городецька Н. Г., Березовецький А. П. Вплив обставин на формування небезпечних ситуацій аграрного виробництва. Вісник Львівського начіонального аграрного університету: агроінженерні дослідження. 2017. № 21. С. 162-166.

3. Городецький I. М., Мазур І. Б., Городецька Н. Г., Ковальчук Ю. О. Використання методів менеджменту безпеки процесів в аграрному виробництві. Вісник Львівського начіонального аграрного університету: агроінженерні дослідження. 2013. № 17. С. 35-39.

4. Кашканов А. А. Математичні методи обгрунтування рішень в автотехнічній експертизі дорожньо-транспортних пригод. Автомобільний транспорт. 2018. Вип. 43. С. 78-89. doi: 10.30977/AT.22198342.2018.43.0.78.

5. Коваленко Л. О. Основні причини скоєння дорожньо-транспортних пригод та їх наслідки. Вісник ХНАДУ. 2019. Вип. 86, т. 2. С. 94-98. doi: 10.30977/BUL.2219-5548.2019.86.2.94.

6. Наявність у домогосподарствах окремих товарів тривалого користування. URL: http://www.ukrstat. gov.ua/ (дата звернення: 07.05.2021).

7. Правила дорожнього руху. URL: https://zakon.rada.gov.ua/laws/show/1306-2001\#Text (дата звернення: 28.05.2021).

8. Сахно В. П., Поляков В. М., Сакно О. П., Колеснікова Т. М. Метод аналізу функціонального резонансу для моделювання контролю безпеки руху автомобіля. Вісник Національного транспортного університету. Технічні науки. 2020. Вип. 1 (46). С. 293 303. doi: 10.33744/2308-6645-2020-1-46-293-303.

9. Сістук В. О., Богачевський А. О., Троян О. В. Підвищення безпеки дорожнього руху на Т-подібному перехресті з переходом в Х-подібне у місті Кривий Ріг. Вісник Наџіонального транспортного університету. Технічні науки. 2016. Вип. 1 (34). С. 447-454.

10. Статистика дорожньо-транспортних пригод в Україні у 2017-2020 pp. URL: http://patrol.police.gov.ua /statystyka/ (дата звернення: 22.04.2021).

11. Статистика смертельних ДТП: скільки українців гине на дорогах зараз і які прогнози влада дає на майбутнє. URL: https://www.slovoidilo.ua/ 2021/02/05/infografika/suspilstvo/statystyka-smertelnyxdtp-skilky-ukrayincziv-hyne-dorohax-zaraz-yaki-prohnozyvlada-daye-majbutnye (дата звернення: 24.05.2021).

12. Статистичні дані виробничого травматизму за галузями у 2017-2019 pp. URL: http://dsp.gov.ua/ статистичні-дані-виробничого-травма-2/ (дата звернення: 22.04.2021).

13. Jurgilewicz M. Bezpieczeństwo samochodów a badania techniczne pojazdów. Вісник Національного транспортного університету. 2014. Вип. 30. С. 389-397.

14. Horodetskyy I. Risk assessment of the system safety in agrarian production. Conditions of Development of Village and Rural Areas. Wroclaw: Uniwersytet Przyrodniczy we Wroclawiu, 2007. P. 19-22. 
15. Hussein N., Hassan R., Fahey M. T. Effect of pavement condition and geometrics at signalised intersections on casualty crashes. Journal of Safety Research. 2021. 76. P. 276-288. doi: 10.1016/j.jsr.2020.12.021.

16. Road traffic injuries. URL: https://www.who.int/ news-room/fact-sheets/detail/road-traffic-injuries (Last accessed: 24.05.2021).

17. Sicińska K. Age of a passenger car and its influence on accidents with fatalities in Poland. Transport problems. 2019. Vol. 14, issue 1. P. 105-113. doi: 10.21307/tp.2019.14.1.10.

18. Singh R., Conjete S., Banerjee R. Assessment of driver stress from physiological signals collected under real time semi urban drivi ng scenarios. International Journal of
Computation Intelligence Systems. 2014. Vol. 7, No. 5. P. 909-923. doi:10.1080/18756891.2013.864478.

19. Song L., Fan W. (David), Li Y., Wu P. Exploring pedestrian injury severities at pedestrian-vehicle crash hotspots with an annual upward trend: A spatiotemporal analysis with latent class random parameter approach. Journal of Safety Research. 2021. 76. P. 184196. doi: 10.1016/j.jsr.2020.12.008.

20. Stepanov A. Active safety in the system of motor-transport safety. Автомобільний транспорт. 2016. Вип. 39. С. 7-13.

21. Zielińska E. Bezpieczeństwo ruchu drogowego w Polsce. Вісник Національного транспортного університету. Технічні науки. 2016. Вип. 2 (35). С. 245-251.

Стаття надійшла 27.08.2021 